\section{Gülfen Tuna ${ }^{1}$}

Sakarya University

Faculty of Management Business

Deparment of International Trade

\section{Şule Yildiz ${ }^{2}$}

Sakarya University

Faculty of Management Business

Deparment of Business Administration
ORIGINAL SCIENTIFIC ARTICLE doi:10.5937/ekonomika1604001T

Received: November 09, 2016

Accepted: November 29, 2016

\title{
THE IMPACT OF OPERATING EXPENDITURES ON FIRM PERFORMANCE IN TURKEY: EVIDENCE FROM TECHNOLOGY SECTOR
}

\begin{abstract}
The purpose of this study is to analyze the effect of operating expenditures consisting of research-development, marketing and general administrative items on firm performance. For that purpose, data of 16 companies for 2008-2015 operating in technology sector trading in Istanbul Stock Exchange were utilized. In the study operating expenditures items (research-development $(R \& D)$, marketingsale-distribution expenditures (MSDE) and general administrative expenditures (GAE)) were used as an independent variable and Return Of Equity (ROE) was used as a dependent variable. The relationship between firm performance and operating expenditures in the study was analyzed through Pedroni Panel Cointegration analysis. According to analysis results, there is a long term relationship between firm performance and operating expenditures items consisting of general administrative expenditures, marketing-sale-distribution expenses and researchdevelopment. When the coefficients for this long term relationship are analyzed, we can see that general administritive expenditures and firm value has an adverse, but marketing-sale-distribution expenditures and research-development has a direct relationship. i.e. while marketing-sale-distribution and research-development expenditures increase firm performance, general administrative expenditures decrease.
\end{abstract}

Key Words: Research and Development (R\&D) Expenditures, Marketing Expenditures, Firm Performance, Technology Sector, Opeating Expenditures, Turkey.

JEL Classification: C33, D22, G32, M21.

\footnotetext{
${ }^{1}$ geksi@sakarya.edu.tr

${ }^{2}$ kasapoglu@sakarya.edu.tr 


\title{
УТИЦАЈ ОПЕРАТИВНИХ ТРОШКОВА НА ПРЕФОРМАНСЕ ФИРМИ У ТУРСКОЈ: ДОКАЗИ ИЗ ТЕХНОЛОШКОГ СЕКТОРА
}

\begin{abstract}
Апстракт
Циљ ове студије је да се анализира утицај оперативних трошкова који се састоја од истраживања-развоја, маркетинга и општих административних ставки на перформансе фирме. За ту сврху су коришћени подаци о 16 предузећа за 2008-2015 који послују у технолошком сектору трговине на Истанбулској берзи. У студији оперативних трошкова ставке (истраживачко-развојних (R\&D), трошкови маркетинга-продаје-дистрибуичије (MSDE) и општих административних трошкова (GAE)) коришћени су као независна варијабла и повратак капитала (ROE) је коришћен као зависна варијабла . Однос између оперативних трошкова пословања фирми у студији је анализиран кроз Педрони панел коинтеграционе анализе. Према резултатима анализе, постоји дугорочна веза између расхода пословања фирми и радних предмета који се састоје од општих административних трошкова, трошкова маркетинг-продаје-дистрибуције и истраживачко-развојних трошкова. Када се анализирају коефиичјенти за овај дугорочни однос, можемо видети да општи администритивни расходи и вредност фирме су негативни, али трошкови маркетинг-продаје-дистрибуције и истраживачко-развојни трошкови имају директну везу, односно док маркетинг-продаја-дистрибутиција и истраживачко-развојни трошкови чврсто повећавају перформансе, општи административни трошкови се смањују.
\end{abstract}

Кључне речи: Истраживање и развој (R\&D), расходи, маркетинг трошкови, перформансе фирме, технолошки сектор, оперативни трошкови, Турска.

\section{Introduction}

Research-development and marketing-oriented investments are significant determiners for businesses to reach their long term sustainable growth and profit targets in fierce competitiveness. In today's conditions, the businesses which are faster than their rivals in producing new products, services, projects and technology and developing current system and products, provide changing customer demands with quality and lower costs, emphasize customer satisfaction and loyalty with customer-centered understanding, after all conduct a good marketing and research and development strategy create difference and become successful.

$\mathrm{R} \& \mathrm{D}$ in broad meaning is the use of creative effort and the knowledge conducted at a systematic base in new applications in order to increase scientific and technical knowledge. In narrow meaning R\&D is a systematic and productive study for emerging new products and new production processes in businesses (Ünal and Seçilmiş, 2014: 203 qouting from Barutçugil, 1981: 17). As the importance to innovation and knowledgebased production and R\&D expenditures increase in businesses, new technologies 
providing cost and time saving in production process can be used, sales and profitability increase through the developed new products and as a result of this efficiency and productivity increases can be provided.

Besides R\&D, another key factor for the businesses to be successful in their activation markets is the marketing activities. Marketing activities are the expenditures that may contribute to increase also the firm and brand value besides realizing the traditional targets such as changing the customer attitudes, providing custumer addiction, increasing the sales or market shares (Topuz and Akşit, 2013: 54 quoting from Day and Fahey, 1988). i.e. all marketing activities aim to provide incomes by creating a value for customers. Also marketing expenditures are expected to increase the expected incomes of the firm in future by creating a positive effect on brand awareness and value and affect the firm value positively with the increasing demand of the investors for the stock (Ç1tak, 2015:50 quoting from Simon, Sullivan, 1993: 32:).

Although there is an expenditure item under the headline of operating expenditures in marketing and R\&D expenditures income statement, indeed these expenditures should be considered as investment tools that would increase the sales, profitability and cash flows of the business, therefore the firm value especially in long term. Thus, positive relationships were identified between R\&D and marketing expenditures and firm profitability and firm value in studies analyzing the relationship between operating expenditures and firm performance in general. Certain variables such as net profit for the year, operation profit, pre-tax profit, assets profitability, Tobin Q rate, equity profitability, market value, investment profitability, stock income rate, sale profitability are generally observed to be used as a performance indicator in related studies. The firms that can change rapidly for technological developments have the potential for both high profitability and long life as the leaders in their sectors. At that point R\&D expenditures for technology firms is very important for protecting their current market potentials and having an absolute life by developing constantly. Finding place of newly developed products in current market most effectively would be possible through an effective marketing strategy and management. At that point, these three items constructing operating expenditures gain much more importance for technology firms. Thus, this study is important for the firms included in the analysis. Moreover, the use of up-to-date econometrical methods in the study besides the commonly used statistical methods is also important for the reliability of the results. Therefore, this study differs from the current studies in terms of analyzed period, used analysis methods and sampling.

Finally, when general administrative expenditures in operating expenditures that will be included in the analysis are analyzed as concept within the firms trading in Istanbul Stock Exchange, we can see that the expenditures of administrators such as wages, journeys, counselling, education, communication have a great role. Therefore, since these expenditures are related with the decisions of administrators at general administration status, the increase in general administrative expenditures is expected to cause a positive effect on sale profitability in the sector (Çiftçi, 2014:239). Indeed, the people who are supposed to make rapid and correct decisions about many topics with strategic importance apart from marketing and research-development and act dinamically in following improvements in rapidly changing competitiveness ang get in harmony are the educated experienced risk-taking administrators with vision. Therefore, while general administrative expenditures increase the profitability on one hand, administrative wages 
will also increase in parallel with the profitability increase as a result of correct decisions on the other hand.

The purpose of this study is to analyze the effects of $R \& D$ and marketing expenditures by technology firms trading in İstanbul Stock Exchange on firm performance (profitability). For that purpose, data of 16 firms registered to İstanbul Stock Exchange for 2008-2015 were utilized. The study consists of four parts. After the introduction part in second part the literature review about the topic is included, however, in third part models and variables used in empirical analyses are introduced. Analysis results are included in fourth parth. In last part a general evaluation is made on ths basis of obtained results.

\section{Literature review}

In literature there are studies analyzing the relationship between $R \& D$ and marketing expenditures and financial performance in different perspectives. In most of these studies operating expenditures are not examined as a whole, but the relationship between R\&D expenditures-firm performance or marketing expenditures-firm performance separately is tried to be established. In the following, studies dealing with the relationship between $\mathrm{R} \& \mathrm{D}$ and marketing expenditures and firm performance of companies in international and national literatures will be included.

In a study by Paton and Williams (1999) using 1991-1993 data of 325 English firms it was identified that marketing expenditures were effective on firm performances. In a study by Yücel and Kurt (2003) in order to measure the effect of marketing and R\&D expenditures on business profitability and sales, 2001 data of 64 firms registered to İstanbul Stock Exchange were utilized. As a result of the study, it was found out that marketing expenditures were positively related with operating profits and sales but negatively related with net profits, however; there was not a significant relationship between R\&D expenditures and profitability and sales.

Tsai and Wang (2004) in their studies that they analyzed the effect of R\&D expenditures on firm performance used 1994-2000 data of 136 firms operating in Taiwan and as a result of the study they identified a positive relationship between R\&D and firm income rates.

In a study by Shah and Stark (2005) on firms operating in England and covering 1990-1998, it was determined that marketing expenditures had a significant effect on market values and future profits of firms.

In a study by Conchar, Crask and Zinkhan (2005), on USA firms between 1985 2004 period using least squares method a positive relationship was concluded between marketing expenditures and firm performance.

Czarnitzki and Kraft (2006) determined that R\&D expenditures in determining credit rating had a positive effect in West Germany, but negative in East Germany in a study result that they analyzed the effect of $R \& D$ expenditures on credit ratings of the firms and financial difficulties.

Ogawa (2007) in his study that they analyzed the relationship between borrowings and R\&D expenditures found that unpaid borrowings for 1988-2001 period in Japanese manufacturing firms with intensive $R \& D$ expenditures had a negative statistically 
significant effect on R\&D expenditures. Moreover, significant relationships were observed between R\&D expenditures and total productivity growth at firm level in the study.

Qureshi (2007) in his study by using 1998-2003 periodical data of the firms operating in England utilizing least square method found a positive and statistically significant relationship between marketing expenditures and market performance.

Anagnostopoulou and Levis (2008) in their studies that they analyzed the relationship between $R \& D$ expenditures and firm performance by using the data of 2182 English firm between 1990-2003 period found a positive relationship between R\&D intensity and sales and the growth in gross income. Also in the study significant relationships were found out between $R \& D$ intensity and abnormal stock incomes corrected according to risk and R\&D intensity was identified to create sustainability in abnormal stock incomes.

Anindita, Prashant and Anantha (2008) in their studies using 2000-2007 periodical data of 172 firms in India used multi regression, Anova and correlation methods and as a result of the studies they obtained a statistically non-significant relationship between marketing expenditures and Tobin's Q and profitability.

In a study by Krasnikov ve Jayachandran (2008) positive and statistically significant results were obtained between marketing and R\&D and firm performance, but the level of relationship between marketing expenditures and performance was found higher.

Karacaer, Aygün and İç (2009) in their regression, correlation and t-test results using the data of 84 firms registered to İstanbul Stock Exchange identified a positive relationship between research and development expenditures and stock profits and asset profitability. Also as a result of the research it was seen that the firms with R\&D activities had larger and more personnels.

Krishnan, Tadepalli and Park (2009) in their studies based 201 American firms and researched whether the firms with more R\&D and marketing investments had higher performances through regression analysis. As a result of the research, it was found out that while R\&D investments did not affect the performance alone, marketing investments affected.

Morgan and Rego (2009) in their studies on 72 American firms found a positive relationship between marketing expenditures and cash flow levels of the firms, but a negative relationship between cash flow variables. However, no relationship was found out between marketing expenditures and Tobin Q.

Çifci, Doğanay and Gülşen (2010) in their studies made the panel data analysis by using 2000-2008 periodical data of 82 firms registered to İstanbul Stock Exchange. As a result of the study, it was identified that marketing expenditures, general administritive expenditures and size of total assets affected the performance of the businesses positively and the most important variable among these was the marketing expenditures.

Siong (2010) also used the least squares method in his research on firms registered to Malaysia Stock Exchange for 2004-2008 period and found a positive and statistically significant relationship between marketing expenditures and firm performance.

Bogliacino and Pianta (2010) used 1994-2006 periodical data of 38 firms in manufacturing sector in different countries in the study that they researched the effect of $\mathrm{R} \& \mathrm{D}$ activities and innovative approaches on profitability and concluded that on-going and past R\&D expenditures had a significant effect on the profit. 
Candemir and Zalluhoğlu (2011) analyzed 1997-2010 periodical data of nine firms in food sector on İstanbul Stock Exchange through panel data regression analysis in their study that they analyzed the effects of marketing expenditures, research-development expenditures and some macroeconomical variables (growth, inflation) on firm performance for especially crisis periods. As a result of the analysis, a positive significant relationship was identified between marketing and R\&D expenditures and net sales and it was found out that increasing marketing expenditures in crisis periods had positive effects.

The effect of marketing expenditures of the businesses on stock profits was analyzed through panel regression analysis by Topuz and Akşit (2013) using 20002010 periodical data of 18 firms in İstanbul Stock Exchange food sector. Study results indicated that marketing expenditures in general had a positive effect on stock profits in current period and the relationship between marketing expenditures and stock profits was concave.

Ünal and Seçilmiş (2014) in their study analyzed the efficiency of R\&D expenditures of 2005-2010 period for 29 firms in Gaziantep on firm sales and the profitability on R\&D expenditures through dinamic panel data model. As a result of the research, a positive relationship was found between $R \& D$ expenditures and net sales of the firms and periodical net profits and R\&D expenditures.

Kocamış and Güngör (2014) analyzed the effect of R\&D expenditures of the businesses on profitability by using 2009-2013 periodical data of 16 firms in İstanbul Stock Exchange technology sector through SPSS. As a result of the study, a positive significant relationship was identified between profitability values consisting of R\&D expenditures and operating profit of the firms, pre-tax profit and net profit for the period.

Çiftçi (2014) in his study researched the effect of R\&D expenditures, advertizingmarketing-distribution expenditures and general administrative expenditures on gross profit margin by using 1998-2009 periodical annual data of the firms in manufacturing industry sector in Turkey. As a result of the study, it was identified that in small scaled firms only marketing expenditures, in middle scaled firms R\&D expenditures and marketing expenditures and in large scaled firms all variables had a positive effect on profits.

Doğan and Mecek (2015) used multi regression and correlation analysis methods in their study that they researched the effect of marketing expenditures on firm value using 2009-2012 data of 120 firms trading in İstanbul Stock Exchange in manufacturing sector. In the study "Return of Assets" (ROA) and "Return of Equity" (ROE) and Tobin's q (Q) rate, market-based performance indicator, were used. A positive and statistically significant relationship was identified between marketing expenditures and firm value as a result of conducted analysis.

Makizadeh and Abtahi (2015) in their study analyzed the effect of marketing expenditures on net sales by using 2002-2012 periodical data of 25 firms in İran. As a result of the study in which dinamic panel data model was used, it was identified that increasing marketing expenditures especially in financial crisis periods and recession period after crisis would increase net sales.

As a result of a gradual regression analysis by Yücel and Ahmetoğulları (2015) using 2000-2014 data of 135 firms in technology, software and information sector registered to İstanbul Stock Exchange, an isochronal positive relationship was identified between the change in R\&D expenditures and the change in net profits. Again, the effect of $R \& D$ expenditures on the profits per stocks was identified as three-term lagged. 
Ç1tak (2015) in his study that he analyzed the effect of marketing investments on firm performance made data cladding analysis by using 2012-2013 periodical data of the firms in İstanbul Stock Exchange SME Industry Index. As a result of the study it was found out that the efficiency of marketing investments of SME was low in general, however; the scale efficiency of the firms with higher asset size was larger than the ones with lower asset size.

$\mathrm{Xu}$ and Jin (2016) analyzed the lagged and cumulative effect of R\&D expenditures on firm performance by using 2011-2013 periodical data of 30 firms registered to Shanghai Stock Exchange. As a result of this study in which Multi Lineer regression model was used, it was identified that R\&D expenditures did not have a significant effect on current firm performance, however; they increased the profit margin at first lag stage and at the end the cumulative effect of $R \& D$ expenditures on firm performance was negative.

Chua et.al, (2016) analyzed the relationship between R\&D expenditures and firm performance through panel data model by using 2008-2011 periodical data of 593 manufacturing firms in total from 8 countries. As a result of the study they identified a positive relationship between sales, profitability and cash flow and R\&D expenditures.

\section{Methodology}

In the research the existence of a long term relationhip between operating expenditures consisting of R\&D, MSDE and GAE of the frims in İstanbul Stock Exchange Technology Sector and firm performance was analyzed through Pedroni Panel Cointegration analyzsis. Before this analysis unit root analysis of the variables was carried out with Levin, Lin, Chu (2002) and Im, Pesaran and Shin (2003). However, long term relationhip coefficients were estimated with FMOLS.

\subsection{Unit Root Tests}

The null hypothesis for the presence of common unit root in the panel is tested in Levin, Lin, Chu (2002) panel unit root test. In this test Augmented Dickey Fuller (ADF) equation is used.

$$
\Delta y_{i t}=\delta y_{i t-1}+\sum_{j=1}^{P_{i}} \beta_{i j} \Delta y_{i t-j}+X_{i t}^{\prime} \alpha+\varepsilon_{i t}
$$

In the equation above

$\mathrm{i}=1,2, \ldots ., \mathrm{N}$ represents cross-section units,

$\mathrm{t}=1,2, \ldots$.Ti represents time dimension,

Xit, indicates a stable effect or external variables including individual trend component,

cit, indicates independent error terms and pi, indicates the lag length. With this test;

$\mathrm{H} 0: \delta=0$

$\mathrm{H} 1: \delta<0$ hypotheses are analyzed. 
If the coefficient is not equal to null under $\mathrm{H} 0: \delta=0$ hypothesis, we decide that the series do not have unit root (Levin et.al, 2002:4-8).

However, in Im, Peseran and Shin (2003) test the null hypothesis for the presence of individual unit root in the panel is tested unlike Levin, Lin, Chu (2002) panel unit root test. The model handled in Im, Peseran and Shin (2003) is as following:

$$
\Delta y_{i t}=\alpha_{i}+\beta_{i} t+\rho_{i} y_{i t-1}+\sum_{j=1}^{k} \emptyset_{k} \Delta y_{i t-j}+u_{i t}
$$

First of all, a different ADF test is implemented for each cross-section in the panel in Im, Peseran and Shin (2003) test and the average of individual ADF statistics is calculated to get the unit root test statistics in the panel. Hypotheses created according to Im, Peseran and Shin (2003) test are:

H0: Panel is rooted.

H1: At least one cross-section is stable.

While the tested main hypothesis Im, Peseran and Shin (2003) test indicates that all series in the panel are not stable, alternative hypothesis tests that some of the series are stable.

\subsection{Panel Cointegration Test}

After analyzing the unit roots, whether there was a long term relationship between the series through Pedroni Panekl Cointegration analysis. Not only this test allows only dynamic and stable effects to be different between the sections of the panel but also it allows the cointegrated vectors to be different between sections as well (Güvenek and Alptekin, 2010: 181). The following hypotheses are tested through Pedroni Panel Cointegration test (Pedroni, 2004:599).

Ho: There is no cointegration relationship for all cross-sections.

H1: There is a cointegration relationship for all cross-sections.

In Pedroni Cointegration analysis seven different cointegration tests are presented in order to cover the effects within the sections and between the sections in the panel. These tests consist of 4 pooled tests in "within" dimensions and other 3 tests in "between" dimension (Asteriou and Hall, 2007: 374).

$$
\begin{aligned}
& \text { Panel v-Statistic } \quad \mathrm{Z}_{\mathrm{v}}=\mathrm{T}^{2} \mathrm{~N}^{\frac{3}{2}}\left(\sum_{\mathrm{i}=1}^{\mathrm{N}} \sum_{\mathrm{t}=1}^{\mathrm{T}} \hat{\mathrm{L}}_{1 \mathrm{i}}^{-2} \hat{\mathrm{e}}_{\mathrm{i}, \mathrm{t}-1}^{2}\right)^{-1} \\
& \text { Panel } \rho \text { - Statistic } \mathrm{Z}_{\rho}=\mathrm{T} \sqrt{\mathrm{N}}\left(\sum_{\mathrm{i}=1}^{\mathrm{N}} \sum_{\mathrm{t}=1}^{\mathrm{T}} \hat{\mathrm{L}}_{11 \mathrm{i}}^{-2} \hat{\mathrm{e}}_{\mathrm{i}, \mathrm{t}-1}^{2}\right)^{-1} \sum_{\mathrm{i}=1}^{\mathrm{N}} \sum_{\mathrm{t}=1}^{\mathrm{T}} \hat{\mathrm{L}}_{11 \mathrm{i}}^{-2}\left(\hat{\mathrm{e}}_{\mathrm{i}, \mathrm{t}-1} \Delta \hat{\mathrm{e}}_{\mathrm{i}, \mathrm{t}-1}-\hat{\lambda}_{\mathrm{i}}\right) \\
& \begin{array}{c}
\text { Panel } \mathrm{t} \text { - Statistic } \\
\text { (Non - Parametric) }
\end{array} \mathrm{Z}_{\mathrm{t}}=\left(\hat{\sigma}_{\mathrm{N}, \mathrm{T}}^{2} \sum_{\mathrm{i}=1}^{\mathrm{N}} \sum_{\mathrm{t}=1}^{\mathrm{T}} \hat{\mathrm{L}}_{11 \mathrm{i}}^{-2} \hat{\mathrm{e}}_{\mathrm{i}, \mathrm{t}-1}^{2}\right)^{-\frac{1}{2}} \sum_{\mathrm{i}=1}^{\mathrm{N}} \sum_{\mathrm{t}=1}^{\mathrm{T}} \hat{\mathrm{L}}_{11 \mathrm{i}}^{-2}\left(\hat{\mathrm{e}}_{\mathrm{i}, \mathrm{t}-1} \Delta \hat{\mathrm{e}}_{\mathrm{i}, \mathrm{t}-1}-\hat{\lambda}_{\mathrm{i}}\right) \\
& \text { Panel t - Statistic(Parametric) } \mathrm{Z}_{\mathrm{t}}^{*}=\left(\mathrm{S}_{\mathrm{N}, \mathrm{T}}^{* 2} \sum_{\mathrm{i}=1}^{\mathrm{N}} \sum_{\mathrm{t}=1}^{\mathrm{T}} \hat{\mathrm{L}}_{11 \mathrm{i}}^{-2} \hat{\mathrm{e}}_{\mathrm{i}, \mathrm{t}-1}^{2}\right)^{-\frac{1}{2}} \sum_{\mathrm{i}=1}^{\mathrm{N}} \sum_{\mathrm{t}=1}^{\mathrm{T}} \hat{\mathrm{L}}_{11 \mathrm{i}}^{-2} \hat{\mathrm{e}}_{\mathrm{i}, \mathrm{t}-1}^{*} \Delta \hat{\mathrm{e}}_{\mathrm{i}, \mathrm{t}}^{*}
\end{aligned}
$$




$$
\begin{aligned}
& \text { Group } \left.\mathrm{p}-\text { Statistic } \mathrm{Z}_{\mathrm{p}}=\mathrm{TN}^{-\frac{1}{2}} \sum_{\mathrm{i}=1}^{\mathrm{N}}\left(\sum_{\mathrm{t}=1}^{\mathrm{T}} \hat{\mathrm{e}}_{\mathrm{i}, \mathrm{t}-1}^{2}\right)^{-1} \sum_{\mathrm{t}=1}^{\mathrm{T}} \hat{\mathrm{e}}_{\mathrm{i}, \mathrm{t}-1} \Delta \hat{\mathrm{e}}_{\mathrm{i}, \mathrm{t}}-\hat{\lambda}_{\mathrm{i}}\right) \\
& \text { Group } \mathrm{t} \text { - Statistic (NonParametric) } \mathrm{Z}_{\mathrm{t}}=\mathrm{N}^{-\frac{1}{2}} \sum_{\mathrm{i}=1}^{\mathrm{N}}\left(\hat{\mathrm{\sigma}}_{\mathrm{i}}^{2} \sum_{\mathrm{t}=1}^{\mathrm{T}} \hat{\mathrm{e}}_{\mathrm{i}, \mathrm{t}-1}^{2}\right)^{-\frac{1}{2}} \sum_{\mathrm{t}=1}^{\mathrm{T}} \hat{\mathrm{e}}_{\mathrm{i}, \mathrm{t}-1} \Delta \hat{\mathrm{e}}_{\mathrm{i}, \mathrm{t}}-\hat{\lambda}_{\mathrm{i}} \text { ) } \\
& \text { Group } \left.\mathrm{t}-\text { Statistic(Parametric) } \mathrm{Z}_{\mathrm{t}}^{*}=\mathrm{N}^{-\frac{1}{2}} \sum_{\mathrm{i}=1}^{\mathrm{N}} \sum_{\mathrm{t}=1}^{\mathrm{T}} \hat{\mathrm{S}}_{\mathrm{i}}^{* 2} \hat{\mathrm{e}}_{\mathrm{i}, \mathrm{t}-1}^{* 2}\right)^{-\frac{1}{2}} \sum_{\mathrm{t}=1}^{\mathrm{T}} \hat{\mathrm{e}}_{\mathrm{i}, \mathrm{t}-1}^{*} \Delta \hat{\mathrm{e}}_{\mathrm{i}, \mathrm{t}}^{*}
\end{aligned}
$$

If the calculated statistics are higher than the critical values, the null hypothesis is rejected. We decide that there is a long term cointegration relationship between the variables included in the analysis. The long term coefficients between the variables with long term relationship were estimated according to FMOLS method. This method is implemented as two stages. Firstly, each cross-section is estimated by using FMOLS estimator. Then, the average of cointegration coefficients obtained from FMOLS estimation belonging to each cross-section is taken. t-statistics of group average panel FMOLS estimators are obtained by taking the average t-statistics belonging to cointegration coefficient obtained from FMOLS estimation for each cross-section.

\section{Data set}

Data set used in the research consists of the operating expenditure items and return of equity of the firms in Istanbul Stock Exchange Technology Sector. The data within the research were obtained from the balance sheets and income statements of related firms. Related financial statements were taken from www.kap.gov.tr. Research period is between 2008 and 2015. All analyses were for 16 firms in 8 year of period. According to this, the firms included in research scope are as in Table 1.

Table 1. Name of Firms Included In The Research

Table 1. Name of Firms Included In The Research

\begin{tabular}{lll}
\hline \hline \multicolumn{2}{c}{ CODE } & NAME OF FIRM \\
\hline \hline 1 & ALCTL & ALCATEL LUCENT TELETAŞ \\
2 & ANELT & ANEL TELEKOM. \\
3 & ARENA & ARENA BILGISAYAR \\
5 & ARMDA & ARMADA BILGISAYAR \\
6 & ASELS & ASELSAN \\
7 & DESPC & DATAGATE BILGISAYAR \\
8 & ERICO & DESPEC BILGISAYAR \\
9 & ESCOM & ERICOM TELEKOMÜNIKASYON \\
10 & INDES & ESCORT TEKNOLOJI \\
11 & KAREL & INDEKS BİLGISAYAR \\
12 & KRONT & KAREL ELEKTRONIK \\
13 & LINK & KRON TELEKOMÜNIKASYON \\
14 & LOGO & LOGO YAZILIISAYAR \\
15 & NETAS & NETAŞ TELEKOM. \\
16 & PKART & PLASTIKKART \\
\hline \hline
\end{tabular}


For eight year of period, return of equity (ROE), operating expenditures (general admininistritive expenditures (GAE), marketing-sale-distribution expenditures (MSDE) and research-development (R\&D) of each firm were used. The purpose of this research is to analyze the long term effect of these three items for operating expenditures on firm performance. Therefore, the effect of related operating expenditure items on firm performance is evaluated by identifying the long term relationship between general administrative expenditure, marketing-sale-distribution expenditure and researchdevelopment expenditures.

\section{Empirical results}

Unit root analysis results for operating expenditure items and return of equity variables are as in Table 2.

Table 2. Results of Unit Root Tests

\begin{tabular}{|c|c|c|c|c|}
\hline Variables & LLC & & IPS & \\
\hline \multicolumn{5}{|c|}{ I(0) } \\
\hline & Istatıstics & Prob. & Istatistics & Prob. \\
\hline ROE & $-8,536^{*}$ & 0,000 & 2,258 & 0,988 \\
\hline GAE & $-0,374$ & 0,354 & 2,000 & 0,977 \\
\hline MSDE & $-1,0275$ & 0,152 & 1,955 & 0,974 \\
\hline R\&D & $-0,732$ & 0,231 & $-0,253$ & 0,399 \\
\hline \multicolumn{5}{|c|}{ I(1) } \\
\hline ROE & $-14,897 *$ & 0,000 & $-1,638 * *$ & 0,050 \\
\hline GAE & $-7,080 *$ & 0,000 & $-2,0717 * *$ & 0,019 \\
\hline MSDE & $-11,898^{*}$ & 0,000 & $-3,408^{*}$ & 0,000 \\
\hline R\&D & $-5,234^{*}$ & 0,000 & $-3,150 *$ & 0,000 \\
\hline
\end{tabular}

lag length was determined according to Schwarz information criterion. BarlettKernel method was used in LLC test and Bandwith width was determined by Newey-West method.

According to two different unit root tests implemented for all series, $\mathrm{H}_{\mathrm{o}}$ hypothesis is accepted for level values (except for ROE). Therefore, all series are not stable at $\mathrm{I}(0)$ and include unit root. When the first difference of the series is taken, $\mathrm{H}_{\mathrm{o}}$ hypothesis is rejected. Therefore, all series are stable when they are I(1). i.e. they do not included unit roots.

Pedroni Cointegration Analysis was used in order to identify whether there was a long term relationhip between series after unit roots were researched. The equation established for Pedroni Cointegration Analysis is as following.

$$
\operatorname{ROE}_{\mathrm{it}}=\alpha_{\mathrm{it}}+\beta_{1} \mathrm{GAE}_{\mathrm{it}}+\beta_{2} \mathrm{MSDE}_{\mathrm{it}}+\beta_{3} \mathrm{R} \& \mathrm{D}_{\mathrm{it}}+\mathrm{u}_{\mathrm{it}}
$$


However, Pedroni Cointegration Analysis results implemented for variables are as in Table 3.

Table 3. Results of Pedroni Panel Cointegration

\begin{tabular}{|c|c|c|c|c|}
\hline \multicolumn{5}{|c|}{$\operatorname{ROE}_{\mathrm{it}}=\alpha_{\mathrm{it}}+\beta_{1} \mathrm{GAE}_{\mathrm{it}}+\beta_{2} \mathrm{MSDE}_{\mathrm{it}}+\beta_{3} \mathrm{R} \& D_{\mathrm{it}}+\mathrm{u}_{\mathrm{it}}$} \\
\hline \multicolumn{5}{|c|}{ Within-Dimension } \\
\hline & \multicolumn{4}{|c|}{ Weighted } \\
\hline & $\underline{\text { Statistic }}$ & Prob. & $\underline{\text { Statistic }}$ & Prob. \\
\hline Panel v-Statistic & 0.985 & 0.162 & -2.309 & 0.989 \\
\hline Panel rho-Statistic & 0.782 & 0.783 & 1.644 & 0.949 \\
\hline Panel PP-Statistic & $-9.244 *$ & 0.000 & $-8.540^{*}$ & 0.000 \\
\hline Panel ADF-Statistic & $-6.946^{*}$ & 0.000 & $-4.321 *$ & 0.000 \\
\hline \multicolumn{5}{|l|}{ Between-Dimension } \\
\hline & $\underline{\underline{\text { Statistic }}}$ & Prob. & & \\
\hline Group rho-Statistic & 3.027 & 0.998 & & \\
\hline Group PP-Statistic & $-14.040^{*}$ & 0.000 & & \\
\hline Group ADF-Statistic & $-5.166^{*}$ & 0.000 & & \\
\hline
\end{tabular}

$* \overline{* *, * * * \text { indicate the significance at } 1,5,10 \text { levels, respectively. The relevant lag }}$ length was determined according to Schwarz information criterion.

According to cointegration analysis results, there is a long term relationship between operating expenditures consisting of R\&D, MSDE and GAE and firm performance. Four of the seven different test statistics used for Pedroni Cointegration Analysis support this situation. FMOLS method was implemented for the estimation of coefficients of the long term relationship between operating expenditures and firm performance. However, the coefficients obtained from FMOLS result are as in Table 4.

Table 4. Results of FMOLS

\begin{tabular}{|c|c|c|c|c|}
\hline \multicolumn{5}{|c|}{ 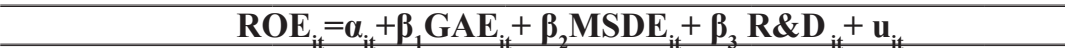 } \\
\hline Variable & Coefficient & Std. Error & t-Statistic & Prob. \\
\hline PAZARLAMA & 3.041 & 1.267 & $2.399 * *$ & 0.019 \\
\hline GYG & -6.300 & 1.412 & $-4.460 *$ & 0.000 \\
\hline ARGE & 3.471 & 0.954 & $3.637 *$ & 0.000 \\
\hline
\end{tabular}

According to Table 4, research-development expenditures and marketingsale-distribution expenditures from operating expenditure items have a positive and statistically significant relationship with firm performance in long term. However, general administritive expenditures have a negative and statistically significant relationship with firm performance. 


\section{Conclusion}

Businesses choose to increase firm values to maximum level as a prior target in order to sustain their existence in financial markets. Return of equity used as an indicator for the firm value consists of net profit and equity amount. At that point, net profit amount is a highly effective value on firm value. However, operating expenditures have an important role in establishing net profit. Operating expenditures have a decreasing effect on establishing net profit figures and these expenditures are essential factors in establishing firm value in long term. In this research the effect of operating expenditures on firm value was also analyzed. For that purpose, 16 firms in Istanbul Stock Exchange Technology sector in 2008-2015 period were included in the research. According to analysis results for 8 year of period with 16 firms, there is a long term relationship between operating expenditures consisting of R\&D, MSDE and GAE and firm value. When the coefficients for this long term relationship are analyzed, we can see that GAE and firm value have a reverse relationship, but MSDE and R\&D have a relationship in the same direction. In other words, while marketing-sale-distribution and research-develepment expenditures increase the firm value, general administrative expenditures decrease it. This situation indicates that the firms in Istanbul Stock Exchange Technology sector will contribute to increase their firm values by making more marketing-sale-distribution and research-develepment expenditures.

The finding of the research that marketing expenditures increase firm performance is coherent with most of the studies in literature (Paton and Williams,1999; Shah and Stark, 2005; Conchar, Crask and Zinkhan, 2005; Qureshi, 2007; Krasnikov and Jayachandran, 2008; Krishnan, Tadepalli and Park, 2009; Çifci, Doğanay and Gülşen, 2010; Siong, 2010; Candemir and Zalluhoğlu, 2011; Topuz and Akşit, 2013; Çiftçi, 2014; Doğan and Mecek, 2015). Also Anindita, Prashant and Anantha (2008) in their study could not identify a statistically significant relationship between marketing expenditures and firm performance.

Similarly, the study finding that $R \& D$ expenditures increase firm value is coherent with some studies in literature. (Tsai and Wang, 2004; Anagnostopoulou and Levis, 2008; Krasnikov and Jayachandran, 2008; Karacaer, Aygün and İç, 2009; Bogliacino and Pianta, 2010; ; Candemir and Zalluhoğlu, 2011; Ünal and Seçilmiş, 2014; Kocamış and Güngör, 2014; Yücel and Ahmetoğullar1, 2015). However, in some studies a negative relationship was identified between $\mathrm{R} \& \mathrm{D}$ and firm performance as different from these study findings. (Guo et. al,2004; Çifci, Doğanay and Gülşen, 2010). Çifci, Doğanay and Gülşen, (2010) stated that this result may occur since there are not stable and regular $R \& D$ expenditures especially in our country and there are not any R\&D expenditures in most of the firms in analyzed years. (Çifci, Doğanay and Gülşen, 2010:101). However, Yücel and Kurt (2003) in their study could not identify a significant relationship between two variables.

In the study a negative relationship was identified between general administrative expenditures and firm value and this result is not coherent with Çifci, Doğanay and Gülşen's (2010) study identifying a positive relationship between general administrative expenditures and firm performance. Similarly, Çiftçi (2014) also in his study concluded that general administrative expenditures were more effective on R\&D and marketing. As the reason for this result, the author explains that the effect of administrator qualifications 
and the decisions within this qualifications on profitability is high (Çiftçi, 2014:248). Leahy (2012) and Okwo and Ugwunta (2012) again in their studies identified a positive relationship between general administrative expenditures and firm profitability (Çiftçi, 2014:239). Indeed, when it is considered that the expenditures such as executive wages construct the biggest share in general administrative expenditure items, the increase in profitability is possible as a result of operational decisions especially in R\&D and marketing fields as qualified and professional managers, CEO and counsellors in a firm increase.

Sales and profitability of firms may be increased in long term due to a general marketing strategy stated in other studies with parallel results with study findings in general and supported by an effective R\&D policy with the potential new product/technology/ process development and innovations. Therefore, business administrators should comprehend the long term effect of R\&D and marketing activities on business performance and increase $\mathrm{R} \& \mathrm{D}$ and marketing budget and develop a stable R\&D and marketing strategy and action plans and apply then effectively. This is the only way for businesses to reach sustainable growth, leadership in the market and profitability targets in long term.

\section{References}

Anagnostopoulou, S. C., \& Levis, M. (2008). R\&D and Performance Persistence: Evidence from the United Kingdom. The International Journal of Accounting, 43(3), 293-320.

Anindita K., Prashant K., Anantha M. N. K. (2008). "Advertising And Firm Value: Mapping The Relationship Between Advertising, Profitability And Business Strategy İ India", http://www.iitk.ac.in/infocell/announce/convention/papers/Strategy-05 Anindita\%20Kundu\%20Prashant\%20Kulkarni\%20Anantha\%20Murthy\%20 N.K\%20.pdf (2016)

Asteriou, D., and Hall, S. G. (2007). Applied econometrics: A modern approach using eviews and microfit revised edition. Palgrave Macmillan.

Barutçugil, D.S. (1981). Teknolojik Yenilik ve Arastırma Gelistirme Yönetimi, Bursa, Bursa Basimevi.

Bogliacino, F. \& Pianta, M. (2010). "Profits, R\&D and Innovation: A Model and a Test", IPTS Working Paper on Corporate R\&D and Innovation, May, No.5.

Candemir, A., \& Zalluhoglu, A. E. (2011). The Effect of Marketing Expenditures During Financial Crisis: The Case of Turkey. Procedia-Social and Behavioral Sciences, 24, 291-299.

Chua, S. R., Chong, C. T., Dy, M. C. S., \& Villavicencio, A. M. E. (2016). The Relationship of Corporate Financial Performance and Innovation among Manufacturing Industries. Presented at the DLSU Research Congress 2016, De La Salle University, Manila, Philippines, March 7-9, 1-6.

Conchar, M. P., Crask, M. R., Zinkhan, G. M. (2005). "Market Valuation Models of The Effect of Advertising and Promotional Spending: A Review \& MetaAnalysis." Journal of the Academy of Marketing Science, 33(4): 445-460. 
Czanitzki, D. ve K. Kraft. 2006. "R\&D and Firm Performance in a Transition Economy", Kyklos, 59 (4): 481- 496.

Çıtak, L. (2015). "Pazarlama Yatırımlarının Finansal Performans Üzerindeki Etkisi ve Borsa İstanbul Kobi Sanayi Endeksi Firmalarının Etkinliklerinin Değerlendirilmesi”, Erciyes Üniversitesi İI.B.F. Dergisi, Say1:45, Ocak-Haziran, 49-68.

Çifci, S., Doğanay, M., \& Gülşen, Z. A. (2010). "The Effect of Marketing Expenditures on Business Performance (Pazarlama Giderlerinin İşletme Karlılıkları Üzerindeki Etkisi)." Finans Politik \& Ekonomik Yorumlar, 47(544), 95-102.

Çiftçi, C. (2014). "Türkiye İmalat Sanayinde Ölçek Bazında Karlılık ve Temel Giderler İlişkisi: 1998-2009 Dönemi.” Sosyo-Ekonomi, 2, 229-252.

Day, G., and Fahey L. (1988). "Valuing Market Strategies”, Journal of Marketing, 52 (July), 45-57.

Doğan, M. ve Mecek, G. (2015). "Pazarlama Harcamalarının Firma Değeri Üzerindeki Etkisi Üzerine Bir Araştırma”. İşletme Araştırmaları Dergisi. 7(2).180-194.

Guo, B., Z. Wang ve Y. Shou (2004). "Firm size,R\&D and Performance:A Empirical Analysison Software Industry in China”. International Engineering Management Conference. 613-616.

Güvenek, B. and Alptekin, V. (2010). "Enerji tüketimi ve büyüme ilişkisi: OECD Ülkelerine İlişkin bir panel veri analizi.” Enerji, Piyasa ve Düzenleme 1(2), 172193.

Im, K. S., Pesaran, M. Hashem, Shin, Yongcheol (2003). "Testing for Unit Roots in Heterogeneous Panels". Journal of Econometrics, Vol:115, 53-74.

Karacaer, S., Aygun, M. ve İç, S. (2009). “Araştırma ve Geliştirme Giderlerinin Firma Performansı Üzerindeki Etkisi: İstanbul Menkul Kiymetler Borsası Üzerine Bir İnceleme". MÖDAV Dergisi. 2. 65-86.

Kocamış, T. ve Güngör A.(2014). “Türkiye'de Ar-Ge Harcamaları ve Teknoloji Sektöründe Ar-Ge Giderlerinin Kârlılık Üzerine Etkisi: Borsa İstanbul Uygulaması", Maliye Dergisi, Say1:166, Ocak-Haziran, 127-138.

Kraniskov, A. ve S. Jayachandran. (2008). “ The Relative Impact of Marketin, Research and Development and Operations Capabilities on Firm Performance". Journal of Marketing. 72: 1-11.

Krishnan, Hema A.; Raghu Tadepalli and Daewoo Park (2009). "R\&D Intensity, Marketing Intensity, and Organizational Performance", Journal of Managerial Issues, 21(2), 232-244.

Leahy, A. S. (2012). "The Determinants of Profitebility in the Pharmaceutical Industry", American Journal of Health Sciences, 3 (1), 37-41.

Levin, A., Lin, C. ve Chu, C. (2002). "Unit Root Tests in Panel Data: Asymtotic and Finite-Sample Properties”, Journal of Econometrics, 108, 1 -24.

Makizadeh, M. and Abtahi Y. (2015). "Financial Crises and Marketing Expenditure Effect: Dynamic Panel Data Approach", Journal of Novel Applied Sciences, 4/3, 371-377.

Morgan, N. A. and L. L. Rego (2009). "Brand Portfolio Strategy and Firm Performance,” Journal of Marketing, Vol: 73, No:1, 59-74. 
Ogawa, K. (2007). "Debt, R\&D Investment and Technological Progress: A Panel Study Of Japanese Manufacturing Firms' Behavior During The 1990s”. J. Japanese Int. Economies. 21: 403-423.

Okwo, I.M. and D.O.Ugwunta (2012). "Impact of fims's Input costs on firm Profitability:Evaluation of he Nigerian Brewery Industry", Research Journal of Finance and Accounting, 3 (6),78-89.

Paton, D., Vaughan, W. L. (1999). “Advertising And Firm Performance: Some New Evidence From UK Firms”. Economic Issues. 4, 89-105.

Pedroni, P. (2004). "Panel Cointegration: Asymptotic And Finite Sample Properties Of Pooled Time Series Tests With An Application To The Ppp Hypothesis". Econometric Theory. 20(3), 597-625.

Shah, Z., Stark, A. W. (2004). "On the Value Relevance of Costly Information on Major Media Advertising Expenditures in the UK". Working Paper. Warwick Business School. UK

Simon, C. J. and M. W. Sullivan; (1993). "The Measurement and Determination of Brand Equity: A Financial Approach”, Marketing Science, 12(1), 28-52.

Siong, G. K. (2010). “An Empirical Analysis Advertising Effect On Firm Performance İn The Malaysian Consumer Products Sector”, Technical Report, University Malaysia Sarawak, http://ir.unimas.my/id/eprint/966

Topuz, Y.V. ve Akşit, N. (2013). “İşletmelerin Pazarlama Giderlerinin Hisse Senetleri Getirileri Üzerindeki Etkisi: İMKB Gıda Sektörü Örneği”. Anadolu Üniversitesi Sosyal Bilimler Dergisi, Cilt:13,Sayı:1, 53-60

Tsai, K-H.; Wang J.-C. (2004). “,R\&D Productivity and the Spillover Effects of Hightech Industry on the Traditional Manufacturing Sector: The Case of Taiwan", The World Economy, Volume: 27, Issue :10, 1555-1570,

Ünal, T. ve Seçilmiş, N (2014). "Satış Hâsılatı Artışında Ar-Ge'nin Rolü Ve Kârlılığın Ar-Ge Harcamalarına Etkisi: Gaziantep Örneği”. Yönetim ve Ekonomi Araştırmaları Dergisi, Sayı:22, 203-210.

$\mathrm{Xu}$, J. and Jin, Z. (2016). "Research on the Impact of R\&D Investment on Firm Performance in China's Internet of Things Industry" Journal of Advanced Management Science Vol. 4, No. 2, March, 112-116.

Yücel, T., Kurt G. (2003). “Araştırma-Geliştirme Ve Pazarlama Giderlerinin Firma Karlılı̆̆ Üzerine Etkisi”, İktisat İşletme ve Finans Dergisi, Cilt: 18/ 209, 18-24.

Yücel, R. ve Ahmetoğulları, K. (2015). “AR-GE harcamalarının Firmaların Net Kar Değişimi ve Hisse Başına Karlılığına İnovatif Etkisi: BİST Teknoloji Yazılım ve Bilişim Sektöründe Bir Uygulama”. Abant İzzet Baysal Üniversitesi Sosyal Bilimler Dergisi, Cilt:15,Yı1:15, Sayı:4, 87-104. 